\title{
PENYULUHAN TENTANG IMUNISASI DI PUSKESMAS RAWAT INAP KEMILING BANDAR LAMPUNG
}

DOI: https://doi.org/10.33024/jkpm.v4i5.3706

\author{
Festy Ladyani ${ }^{1}$, Sri Maria Puji Lestari ${ }^{2^{*}}$, Khairunisa Firdani ${ }^{3}$, Resti Arania ${ }^{4}$, \\ Neno Fitriyani ${ }^{5}$, Abdurrohman Izzudin ${ }^{6}$ \\ ${ }^{1-6}$ Fakultas Kedokteran Program Studi KedokteranUniversitas Malahayati \\ Disubmit: 17 Januari 2021 Diterima: 02 Mei 2021 Diterbitkan: 02 Oktober 2021
}

Email Korespondensi: srimaria@gmail.com

\begin{abstract}
ABSTRAK
Tingkat kesehatan pada bayi perlu mendapatkan perhatian mengingat bayiatau anak sebagai penerus Bangsa. Imunisasi merupakan suatu strategi yang efektif dan efisien dalam meningkatkan derajat kesehatan nasional. Alasan beberapa bayi tidak mendapatkan imunisasi lengkap yaitu karena alasan informasi, motivasi dan situasi. Alasan informasi berupa kurangnyapengetahuan ibu tentang kebutuhan, kelengkapan, dan jadwal imunisasi,ketakutan akan imunisasi dan adanya persepsi salah yang beredar di masyarakat tentang imunisasi. Dan yang paling berpengaruh yaitu ketidaktahuan ibu tentang penting nya imunisasi, ketidaktahuan ibu tentang waktu yang tepat untuk imunisasi dan ketakutan akan efek samping dari imunisasi. Berdasarkan survey pendahuluan menunjukkan beberapa posyandu di wilayah puskesmas rawat inap kemiling tidak terdapat poster imunisasi yang mempengaruhi kurangnya pengetahuan ibu tentang imunisasi. Tujuan dari penyuluhan ini yaitu memberikan informasi tentang pentingnya imunisasi pada anak.
\end{abstract}

Kata Kunci : Penyuluhan, Imunisasi, Anak

\begin{abstract}
The level of health in infants needs attention considering that babies or children are the successor of the Nation. Immunization is an effective and efficient strategy in increasing the national health status. The reason some babies do not get complete immunization is due to information, motivation and circumstances. The reasons for the information were in the form of the mother's lack of knowledge about immunization needs, completeness, and schedule, fear of immunization and the wrong perception circulating in the community about immunization. And the most influential thing is the mother's ignorance about the importance of immunization, themother's ignorance about the right time for immunization and fear of side effects of immunization. Based on the preliminary survey, it shows that several posyandu in the inpatient health center area of Kemiling do not have immunization posters whichaffect the lack of knowledge of mothers about immunization. The purpose of this counseling is to provide information about the importance of immunization inchildren.
\end{abstract}

Key Words : Counseling, Immunization, Children 


\section{PENDAHULUAN}

Tingkat kesehatan pada bayi perlu mendapatkan perhatian mengingat bayi atau anak sebagai generasi penersu bangsa (Sari, 2016). Salah satuupaya untuk menjadikan generasi yang sehat yaitu dengan mengurangi morbiditas dan mortalitas pada anak. Selain itu juga dibutuhkan suatu upaya kesehatan yang konsisten (Soetjiningsih, 2012).

Upaya mengurangi tingkat morbiditas dan mortalitas pada anak salah satunya dengan pemberian imunisasi. Imunisasi merupakan salah satustrategy yang efektif dan efesien dalam meningkatkan derajat kesehatan nasional dengan mencegah enam penyakit: tuberculosis, dipteri, pertusis, campak, tetanus dan polio (Anggarini \& Marlin, 2019). WHO mencanangkan program Expanded Program on Immunization (EPI) dengan tujuan untuk meningkatkan cakupan imunisasi pada anak-anak diseluruh dunia sejak tahun 1974 (Ayubi, 2009).

Beberapa alasan bayi tidak mendapatkan imunisasi lengkap yaitu karena alasan informasi, motivasi dan situasi. Alasan informasi berupa kurangnya pengatahuan ibu dengan kebutuhan, kelengkapan, jadwal imunisasi dan ketakutan akan imunisasi dan adanya persepsi salah yang beredar tentang imunisasi (Dewi et al., 2014). Akan tetapi yang paling berpengaruh adalah karena anak sakit, ketidaktahuan ibu akan pentingnya imunisasi dan ketidaktahuan waktu yang tepat untuk mendapatkan imunisasi dan ketakutan akan efek samping yang ditimbulkan setelah imunisasi (Albertina \& Febriana, 2016). Dari uraian tersebut menunjukan bahwa pengetahuan memiliki peranan yang penting terhadap kelengkapan imunisasi pada anak.

Berdasarkan hasil penelitian yang dilakukan oleh Atika (2013) di Kelurahan Parupuk Tabing Kota Padang diketahui bahwa persentase pemberian imunisasi dasar lengkap lebih banyak pada ibu yangpengetahuan nya cukup yaitu sebesar $87,5 \%$ dibandingkan pada ibu berpengetahuan kurang yaitu sebesar $4,3 \%$. Hal ini menunjukkan bahwa peran ibu tentang imunisasi dasar sangat berpengaruh terhadap kelengkapan imunisasi pada bayi atau anak.

Melakukan penyuluhan merupakan salah satu upaya untuk meningkatkan pengetahuan ibu mengenai pentingnya imunisasi padaanak (Mugianti et al., 2018). Sebagai langkah awal untuk meningkatkan kesehatan khususnya pada anak merupakan generasi penerus bangsa ini. Pengetahuan yang baik akan berpengaruh terhadap kelengkapan imunisasi dasar pada anak (Utviaputri, 2018). Tujuan umum dilakukan penyuluhan ini adalah ibu dapat memahami tentang imunisasi dan tujuan khususnya yaitu remaja memahami definisi imunisasi, manfaat imunisasi, penyakit - penyakit yang dapat dicegah oleh imunisasi dan waktu yang tepat untuk melakukan atau mendapatkan imunisasi pada bayiatau anak.

\section{MASALAH}

Kemiling merupakan salah satu kecamatan yang terdapat di Bnadar Lampung. Berdasarkan keterangan yang diperoleh dari masyarakat sekitar khususnya ibu bahwa belum tahu secara jelas tentang imunisasi dasar pada anak. Berdasarkan survey pendahuluanmenunjukkan beberapa posyandu di wilayah puskesmas rawat inap kemiling tidak terdapat poster imunisasi yang mempengaruhi kurangnya pengetahuan ibu tentang imunisasi. 


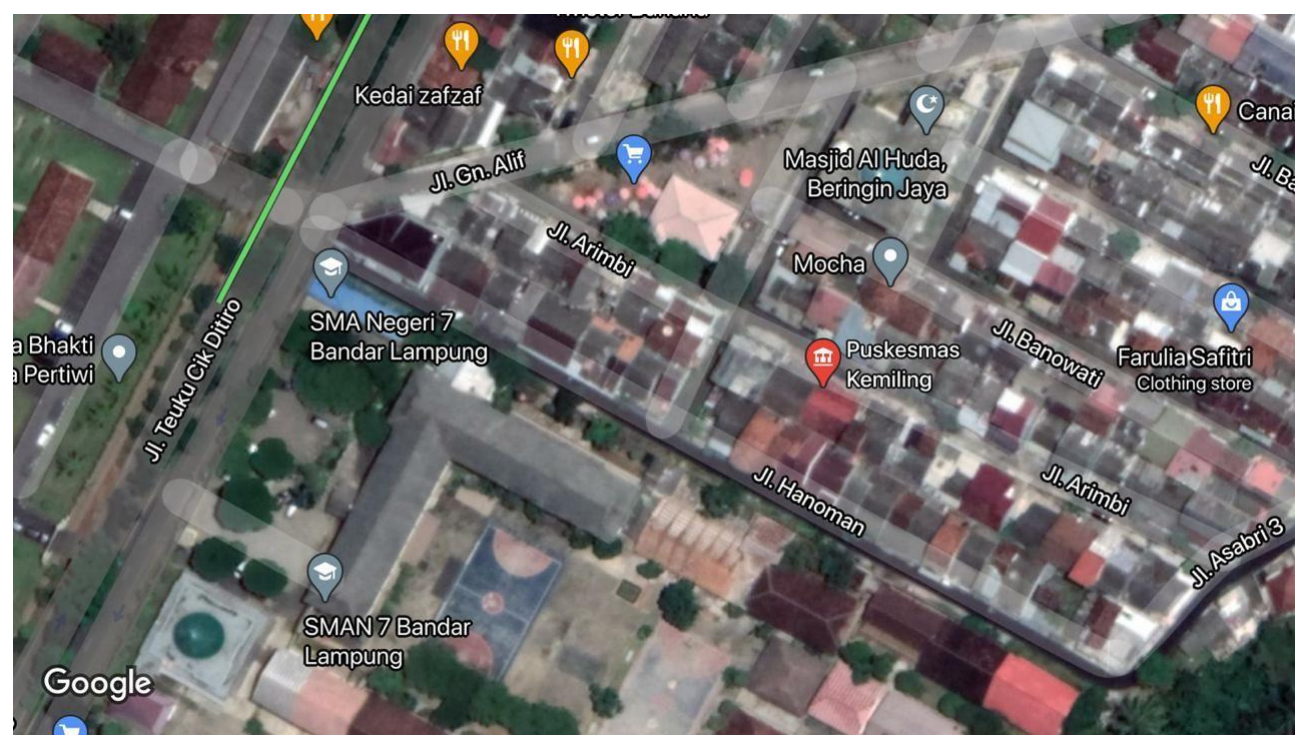

Gambar 2.1 Puskesmas Rawat Inap Kemiling Bandar Lampung

\section{METODE}

1. Tahap persiapan dari kegiatan adalah pembuatan pre planing, mengajukan ijin dan persiapan tempat dan alat - alat lainnya bekerja sama dengan puskesmas rawat inap kemiling Bandar Lampung. Pembuatan power point dan leaflet leaflat dimulai 2 hari sebelum kegiatan penyuluhan dimulai.

2. Tahap Pelaksanaan Acara ini dengan pemberitahuan kepada masyarakat khususnya ibu di wilayah puskesmas rawat inap Kemiling Bandar Lampung oleh salah satu pihak Puskesmastersebut. Dan dilanjutkan penyuluhan kesehatan tentang imunisasi dasar pada anak pada ibu-ibu di wilayah puskesmas rawat inap kemiling Bandar Lampung.

3. Evaluasi

a. Struktur Peserta hadir sebanyak 21 orang. Setting tempat sudah sesuai dengan rencana yang dibuat dan perlengkapan yang dilakukan untuk penyuluhan sudah tersedia dan sudah digunakan sebagaiman mestinya. Penyampaian materi menggunakan bahasa yang mudah dimengerti oleh $\mathrm{dr}$ HannyMuslihah. Dalam penyampaianya, ib-ibu dapat memahami materi yang sudah disampaikan dan selama berjalannya penyuluhan dilakukan diskusi serta Tanya jawab.

b. Proses Pelaksanaan kegiatan pukul 08.30 - 09.30 wib. Sesuai dengan jadwal yang telah direncanakn.

c. Hasil
1. Peserta
dapat memahami
dan mengerti

tentang imunisasi

2. Peserta dapat memahami dan mengerti tentangtujuan imunisasi

3. Peserta dapat memahami dan mengerti tentangmanfaat imunisasi

4. Peserta dapat memahami dan mengerti tentang penyakityang dapat dicegah oleh imunisasi

5. Peserta dapat memahami dan mengerti tentangwaktu yang tepat untuk mendapatkan imunisasi (Alvina et al., 2020) 


\section{HASIL DAN PEMBAHASAN}

Penyuluhan Tentang Imunisasi di wilayah puskesmas rawat inapKemiling Bandar Lampung berjalan dengan tertib dan lancar. Sasarankegiatan pengabdian masyarakat ini adalah seluruh ibu khususnya yang mempunyai bayi atau balita ada diwilayah puskesmas rawat inap kemiling tersebut. Partisipan yang hadir sebanyak 21 Orang.

Berikut gambar pelaksanaan penyuluhan:
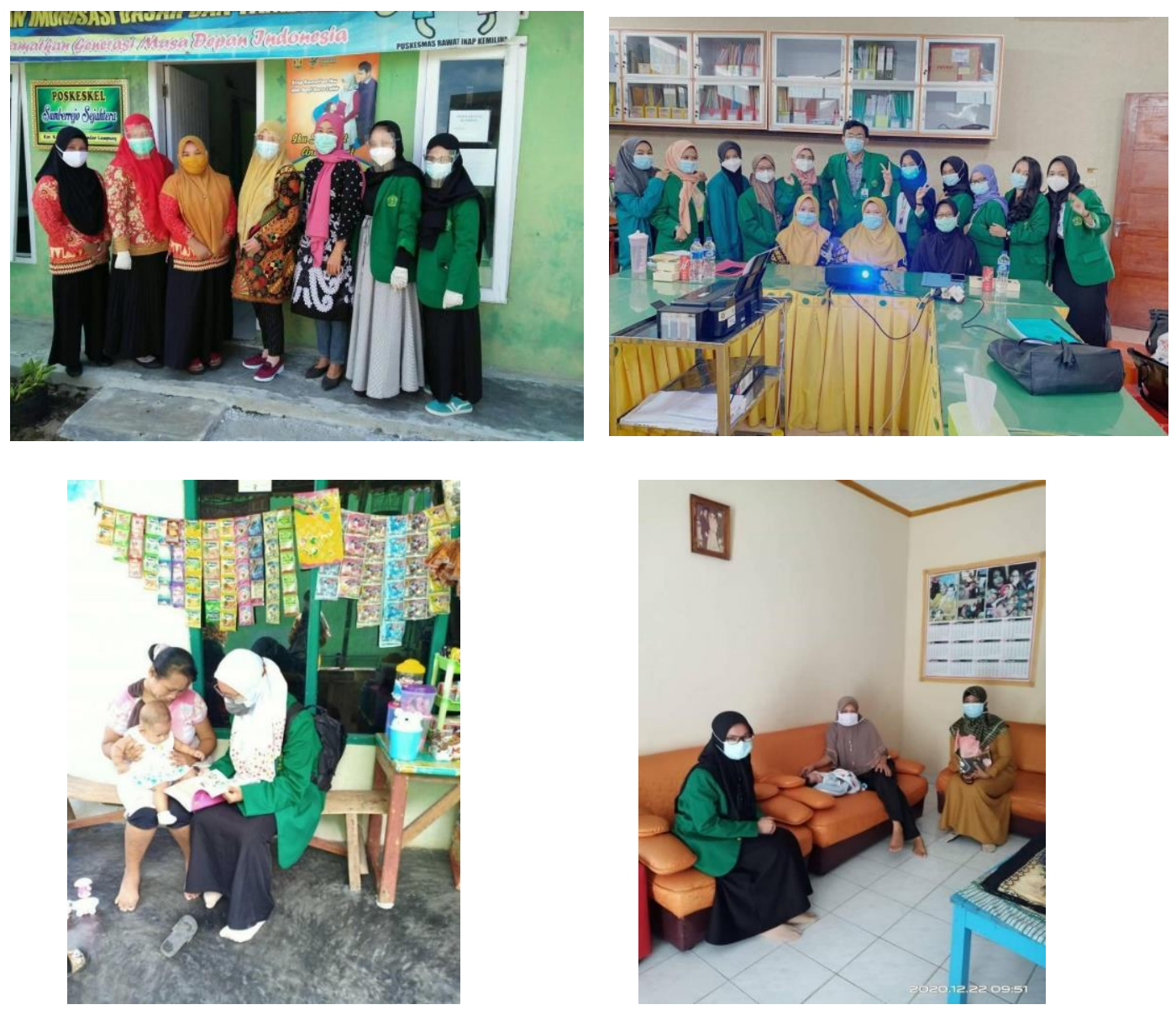

Gambar 4.1 Pelaksanaan Kegiatan Pengabdian Kepada Masyarakat

Dari 21 warga khususnya ibu-ibu diberikan materi penyuluhan tentang imunisasi. ada $3(14 \%)$ Orang yang mengatakan kurang memahami mengenai imunisasi dasar pada anak. Ibu mengatakan terkadang anaknya terlewat jadwal imunisasi dikarenakan belum mengetahui waktu yang tepat untuk mendapatkan imunisasi. Semua ibu-ibu yang hadir diberikan penyuluhan terkait pengetahuan tentang imunisasi dasar pada anak. Setelah diberikan sosialisasi tentang imunisasi dasarpada anak di wilayah puskesmas rawat inap kemiling Bandar Lampung meliputi pengertian imunisasi,tujuan imunisasi, manfaat imunisasi, penyakit-penyakit yang dapat dicegah melalui imunisasi dan waktu yang tepat untuk mendapatkan imunisasi pada anak. Setelah dilakukan evaluasi maka diperoleh $90 \%$ ibu memiliki pemahaman yang baik tentang imunisasi dasar pada anak. Peningkatan rata-rata berkisar $60 \%$ sebelum dan sesudah dilakukan tindakan Penyuluhan imunisasi dasar pada anak. Hal ini dipengaruhi oleh faktor ibu-ibu yang memiliki rasaingin tahu yang besar dalam menerima wawasan salah satunya 
mengenai imunisasi dasar pada anak. Dalam Kegiatan Pengabdian Kepada Masyarakat ini sebelumnya tidak mengalami hambatan karenapihak puskesmas khususnya puskesmas rawat inap kemiling Bandar Lampung sangat mendukung kegiatan ini.

\section{KESIMPULAN}

Dari hasil kegiatan Pengabdian Kepada Masyarakat tentang Penyuluhan Imunisas di Wilayah Puskesmas Rawat Inap Kemiling. Maka disimpulkanadanya peningkatan pengetahuan ibu tentang pentingnya imunisasi meliputi pengertian Imunisasi, Tujuan Imunisasi, Manfaat Imunisasi, Pneyakit yang dapat dicegah dengan imunisasi, Jadwal pemberian imunisasi dengan rata-rata peningkatan sebesar $60 \%$.

\section{DAFTAR PUSTAKA}

Albertina, M., \& Febriana, S. (2016). Kelengkapan Imunisasi Dasar Anak Balita Dan Faktor-Faktor Yang Berhubungan Di Poliklinik Anak Beberapa Rumah Sakit Di Jakarta Dan Sekitarnya Pada Bulan Maret 2008. Sari Pediatri, 11(1), 1-7.

Alvina, A. Z. L., Yanti, R. D., Keb, M., Yanti, R. D., \& Keb, M. (2020). Asuhan Kebidnan Pada Bayi Ny. L Dengan Hiperbilirubin Di Rsud Ciaiw Bogor Poltekkes Kemenkes Bandung].

Anggarini, I. A., \& Marlin, R. (2019). Penyuluhan Kesehatan Tentang Pentingnya Imunisasi Dasar Bagi Bayi Di Desa Sungsang Kecamatan Banyuasin li. Khidmah, 1(2), 145-149.

Atika, P. D. (2013). Hubungan Tingkat Pengetahuan Ibu Dengan Pemberian Imunisasi Dasar Lengkap Pada Bayi Di Kelurahan Parupuk Tabing Wilayah Kerja Puskesmas Lubuk Buaya Kota Padang Tahun 2013 Universitas Andalas].

Ayubi, D. (2009). Kontribusi Pengetahuan Ibu Terhadap Status Imunisasi Anak Di Tujuh Provinsi Di Indonesia. Publikasi Penelitian Terapan Dan Kebijakan, $3(1)$.

Dewi, A. P., Darwin, E., \& Edison, E. (2014). Hubungan Tingkat Pengetahuan Ibu Dengan Pemberian Imunisasi Dasar Lengkap Pada Bayi Di Kelurahan Parupuk Tabing Wilayah Kerja Puskesmas Lubuk Buaya Kota Padang Tahun 2013. Jurnal Kesehatan Andalas, 3(2).

Mugianti, S., Mulyadi, A., Anam, A. K., \& Najah, Z. L. (2018). Faktor Penyebab Anak Stunting Usia 25-60 Bulan Di Kecamatan Sukorejo Kota Blitar. Jurnal Ners Dan Kebidanan (Journal Of Ners And Midwifery), 5(3), 268-278.

Sari, D. N. I. (2016). Hubungan Pengetahuan Ibu Tentang Imunisasi Dasar Dengan Kelengkapan Imunisasi Dasar Bayi Di Wilayah Kerja Puskesmas Bendo Kabupaten Magetan Universitas Muhammadiyah Surakarta].

Soetjiningsih, C. H. (2012). Perkembangan Anak Sejak Pembuahan Sampai Dengan Kanak-Kanak Akhir. Jakarta: Prenada.

Utviaputri, L. P. (2018). Pengaruh Petunjuk Untuk Bertindak Pada Ibu Terhadap Kelengkapan Imunisasi Dasar Anak. Jurnal Promkes: The Indonesian Journal Of Health Promotion And Health Education, 6(1), 46-58. 